\title{
Kreatív turizmus Budapesten - Szabadulószobák az innovatív turisztikai piacon
}

\author{
Szerzők: Nagy Adrienne ${ }^{1}$ - Petykó Csilla² - Kiss Diána Dóra ${ }^{3}$ - Egedy Tamás ${ }^{4}$
}

Az elmúlt évtizedben a városi turizmus kínálatában a hagyományos elemek mellett új, innovatív termékek jelentek meg. A kreatív turizmus különösen olyan desztinációk esetében fejlódik gyorsan, amelyek az élményszerzés és aktivitás új, alternatív formáit keresik és alkalmazzák. A kreatív turizmus egyik új fejlődési iránya a gamifikáció, amikor egy játék áll a turisztikai aktivitás középpontjában, és új vonzerôként ez szolgáltat emlékezetes élményeket a turisták számára. Napjainkban a kreatív turizmus és gamifikáció egyik nemzetközi szinten is legnépszerübb szolgáltatása a szabadulószoba, amelynek európai meghonosításában a magyar szolgáltatók úttörô szerepet játszottak. Tanulmányunkban longitudinális internetes weboldalelemzés, tartalomelemzés, terepbejárás és empirikus megfigyelések eredményein keresztül először rendszerezzük és kategorizáljuk Budapest kreatív turisztikai kínálatát, majd részletesen bemutatjuk a szabadulószoba szolgáltatások kinálati piacát és a szabadulójátékok legfontosabb jellemzőit. A nemzetközi összehasonlítás és konkurenciaelemzés segítségével a budapesti szabadulószoba-piac nemzetközi versenyképességét és pozícióját elemezzük.

Kulcsszavak: kreatív turizmus, gamifikáció, szabadulószobák, Budapest.

\section{Bevezetés}

Az urbanizáció előrehaladásának köszönhetően a városok és a városi létforma globális szinten egyre fontosabb szerepet játszanak (UNITED NATIONS 2014, EU 2016), amihez a turizmus is igazodik. A városok egyre szélesebb és színesebb szolgáltatási palettával vonzzák a turistákat. Mivel a városlátogató turizmus - köszönhetóen sikerességének - egyre inkább a tömegturizmus színterévé vált, a kereslet egyes szegmensei a klasszikus szolgáltatási elemek mellett egyre gyakrabban keresik a niche termékeket (CCN 2008). Az alternatív turizmus és a kreatív turizmus többek között erre az igényre ad választ a városokban.

Egy nagyváros kínálatában az innovatív kínálati elemek megléte vagy hiánya nyilvánvalóan hatást gyakorol a turizmus alakulására. Fontos kérdésként merül fel, hogy Budapest esetében érzékelhetô-e ilyen irányú fejlődés? Ennek megvá-

\footnotetext{
1 egyetemi docens, Budapesti Gazdasági Egyetem, nagy.adrienne@uni-bge.hu

2 egyetemi docens, Budapesti Gazdasági Egyetem, petyko.csilla@uni-bge.hu

3 MSc-hallgató, Budapesti Corvinus Egyetem,

kissmelodia@gmail.com

4 habilitált egyetemi docens, Budapesti Gazdasági Egyetem; tudományos

főmunkatárs, MTA CSFK Földrajztudományi Intézet, egedy@gmx.net
}

laszolására 2014-ben elindítottunk egy kutatást, és több lépcsóben megvizsgáltuk, hogy a főváros szabadidô eltöltési programszolgáltatásaiban milyen változások fedezhetốk fel, valamint a kínálat tartalmaz-e kreatív szolgáltatásokat és innovatív elemeket. Mivel napjainkban a városlátogató turizmusban a fizikai aktivitást biztosító lehetőségek iránt egyre nagyobb igény mutatkozik, a kutatás során elsősorban olyan kínálati elemeket kerestünk, amelyek mindkét elvárásnak megfelelnek, azaz kreatív és egyúttal aktív szolgáltatásokat is nyújtanak.

Budapest az európai fóvárosok versenyében egyelőre keresi a helyét. Tény ugyanakkor, hogy a vendégforgalmi mutatók alakulása alapján a turizmus nemzetközi piacán szerepe lassan, de biztosan nő. Ennek ismeretében fontos annak vizsgálata, hogy a város kínálata lépést tart-e a növekvó kereslettel, és a szolgáltatók kreativitása felfedezhetô-e a kínálat részelemeiben? Tanulmányunk fő célkitúzése annak bemutatása, hogy Budapesten a hagyományos turisztikai kínálat mellett milyen további szolgáltatások jelentek meg, amelyek a szolgáltatók innovativitását mutatják, a turisták részéről pedig kreativitást és aktivitást igényelnek. Írásunk tehát alapvetóen a kínálati oldalon jelentkező szolgáltatásokat veszi górcső alá. Jelen tanulmánynak nem célja a keresleti oldal jellemzőinek feltárása, amelyet a kutatás következó szakaszában vizsgálunk. A keresleti oldal kutatása hosszabb időt igényel, mivel erre vonatkozó statisztikai adatgyúj- 
tés lényegében nem folyik, és egyelőre hiányoznak a kutatáshoz szükséges kiinduló adatbázisok.

A fentiek figyelembevételével tanulmányunkban a következố kérdésekre keressük a választ:

- Hogyan rendszerezhetó és kategorizálható Budapest kreatív és innovatív turisztikai kínálata?

- Mi jellemzi a szabadulószobák budapesti kínálatát?

- Hogyan értékelhetô Budapest pozíciója nemzetközi összehasonlításban a szabadulószobák terén?

\section{A kutatás elméleti háttere - Kreatív turizmus, gamifikáció és szabadulószobák}

Az elmúlt évtizedekben a turizmus nemzetközi piacán a városokban érvényesülő tömegturizmus mellett megjelentek az alternatív turizmus igényeit kielégítő termékek. Ezek a termékek az egyének átlagtól eltérő érdeklődésének kielégítését szolgálják, vagy a szokásostól eltéró módon mutatnak be ismert turisztikai attrakciókat. A turisták egyénileg, vagy kisebb csoportokban vesznek részt a programokon, amelyeknek egy része a turizmus hagyományos területein kívül helyezkedik el (MICHALKÓ 2012, ZÁTORI 2014). Budapest városa a kulturális turizmusban pozícionált termék, kínálatában azonban - az örökségi értékek mellett - megjelentek az újszerú, modern formák is, amelyek a város termékkínálatának fokozatos átalakulását eredményezték (RÁTZ 2015, SMITH et al. 2018). Változatlanul a tömegturizmus kínálata a legjelentősebb, de a specializált niche termékek szerepe egyértelmúen nô a kínálatban. Az alternatív turizmus egyik ilyen specializált terméke a kreatív turizmus. A kreatív turizmus sok lehetőséget kínál azon desztinációk számára, amelyek a turisztikai aktivitás új formáit szeretnék fejleszteni és alkalmazni, illetve a tradicionális termékek mellé új alternatívákat keresnek (RICHARDS 2009).

A kreatív turizmus koncepciója az 1990-es évek közepén jelent meg, maga a fogalom pedig az ezredfordulót követóen terjedt el széles körben a turizmuskutató közösségben (RICHARDS - WILSON 2007, RICHARDS 2011). A 2000-es évek első évtizedében a szakemberek egyértelmúen felismerték a kreativitásban rejlő gazdasági potenciált, és a gazdaságfejlesztés egyik hatékony eszközének tekintették (KEA 2006). A kreatív turizmus két szempontból is fontos volt a szektor továbbfejlődése szempontjából: egyrészt új, inventív termékeivel hozzájárult a turizmus kínálatának megújulásához, másrészt találkozott a turisták megváltozott igényeivel, hogy tartóz- kodásukat új élményelemekkel bővítsék és új tapasztalatokat szerezzenek (SMITH 2006). Nem véletlen, hogy a kreatív turizmus az ezredforduló utáni évtizedben a globális turisztikai piac egyik meghatározó niche részpiacává vált. A kreatív turizmus egyik nagy elónye éppen az, hogy lehetővé teszi a látogatók számára kreativitásuk fejlesztését, miközben aktív résztvevőivé válnak olyan új tapasztalatok megszerzésének, amelyek a választott úti céljuk egyedi jellegzetességeihez kötődnek (RICHARDS - RAYMOND 2000). A kreatív turizmus termékeivel leggyakrabban a múvészetek és iparmúvészet, dizájn, szakácsmúvészet, gasztronómia és borkészítés, egészség és gyógyítás, nyelvek, spiritualitás, táj és természet, sport és kikapcsolódás területén találkozhatunk. A kreatív turizmust a kutatók immár harmadik generációs turizmusfajtának tekintik, amelyben a turisták fő motivációját a helyi lakossággal való találkozás, az élő kultúra személyes, alkotó módon való megtapasztalása jelenti.

A XXI. század új, alternatív turisztikai termékek megjelenését is magával hozta. Új színfoltját jelentette a turisztikai termékeknek a különbözó játékok elterjedése a turisztikai piacon. A turizmus gamifikációja vadonatúj kutatási témaként jelent meg a nemzetközi szakirodalomban, azonban a témakör újdonsága miatt a nemzetközi és hazai publikációk száma még csekély (SIGALA 2015, XU et al. 2014, CORREA - KITANO 2015, NEGRUŞA et al. 2015). DETERTING és szerzőtársainak (2011) általánosan elfogadott definíciója szerint a gamifikáció során magát a játékot az eredeti, megszokott kontextusától eltérő módon és céllal alkalmazzuk. Jelen esetben a szabadulószobák az üzleti vállalkozások kínálatában, jelentős potenciállal rendelkező turisztikai termékként jelennek meg. A gamifikáció egy rendkívül gyorsan változó jelenség a turizmuson belül (BOES et al. 2015), amit jól mutat a szabadulószobák számában és tematikájában végbement változás (lásd kutatási eredményeinket a tanulmány 4 . fejezetében). A gamifikáció középpontjában a játék áll, amely SEABORN és FELS (2015) szerint meghatározott szabályok szerint folyik, sajátos struktúrája van, önkéntes részvételen alapul és mindig valamilyen eredménnyel, megoldással zárul. A folyamatban kiemelt szerepe van a résztvevők aktivitásának és interakciójának. A World Travel Market már 2011-ben előre jelezte, hogy a gamifikáció a turizmus rendkívül népszerú és gyorsan fejlődő trendje lesz, amely emlékezetes és maradandó turisztikai élményeket nyújt a programokban résztvevôk számára (WTM 2011, BULENCER - EGGER 2015). A gamifikáció továbbfejlődésében a klasszikus elemek mellett egyre nagyobb 
Lektorált tanulmányok

szerepe lesz a különbözó technológiai eszközöknek és megoldásoknak, úgymint a virtuális és a kibővített valóság (GRETZEL - JAMAL 2009, NEUHOFER et al. 2012). A gamifikáció végsó soron fontos szerepet játszhat a desztináció marketingjében és brandingjében, interaktív természeténél fogva pedig növelheti a turisták érdeklódését és desztinációhúségét (XU et al. 2017).

Az elmúlt évtizedben szerte a világon új, posztmodern attrakciók jelentek meg, amelyek a valóság és a képzelet, vagy a realitás és a hiperrealitás határán mozognak (SHARPLEY 2015). Ezek közé sorolhatók a valósághú szabadulószobák (real-life escape rooms), amelyek a gamifikáció népszerú megjelenési formái szerte a világon. A szolgáltatás 2007-ben jelent meg Japánban, majd a következó évtizedben meghódította az összes kontinenst (NICHOLSON 2015). A játék lényege, hogy egy zárt helyiségből különböző interaktív elméleti és gyakorlati feladatok megoldásán keresztül (például akció-, kaland-, kirakó-, szerep-, szimulációsvagy stratégiai játékok, rejtvényes útmutatások segítségével) eljuthatunk a szoba kinyitásáig, és kiszabadulhatunk. Mindeközben a résztvevők maguk is a történet és a cselekmény aktív részeseivé válnak. A leggyakoribb tematikák a horror, a fantasy, a tudomány, a jövő/új technológiák és a military köréből kerülnek ki. Leggyakoribb megjelenési formái a narratív és teljesen narratív szobák, amikor a résztvevők specifikus szerepeket kapnak, és addig nem hagyhatják el a szobát, amíg a narratívát végig nem játszották (NICHOLSON 2016). A szobákat gyakran a játék tematikájához illeszkedő dekorációval és eszközökkel szerelik fel. A szolgáltatásnak az élményszerzésen kívül a résztvevók tudatos együttmúködésén, a kölcsönös tudás- és ismeretmegosztáson, a párbeszéden és konfliktuskezelésen keresztül távolabbra mutató társadalmi és szociális hatásai is vannak (PAN et al. 2017). A szabadulószobákhoz hasonló szolgáltatások az alternatív valóság játékok (alternate reality games), amelyek nem zárt helyiségekben, hanem szabad téren, nyitott városi terekben zajlanak.

\section{A kutatás módszertani háttere}

2014-ben indítottuk el azt a kutatást, amelynek során több szakaszban vizsgáltuk, hogy Budapest városi turistáknak célzott kínálatában milyen változások fedezhetôk fel, illetve a turisztikai szolgáltató szektor kreatív és aktív kínálatában milyen társadalmi innovációk jelentek meg. Kutatásunk során elsődlegesen nem a kreatív iparágak által teremtett lehetőségeket céloztuk meg, hanem a teljes szabadidős programkínálat kreatív és aktív elemeit próbáltuk összegyúiteni. Arra voltunk kíváncsiak, hogy a fóváros hagyományos kínálata mellett milyen további szolgáltatások jelentek meg a piacon, amelyek a szolgáltatók innovativitását mutatják, a turisták részéről pedig kreativitást és aktivitást igényelnek.

A kutatás első, megalapozó szakasza 2014 szeptembere és decembere között zajlott le. Ebben az időszakban elsősorban az elérhető innovatív, kreatív és aktív szolgáltatások összegyújtésére fókuszáltunk. Abból a feltételezésből indultunk ki, hogy a városi turizmus keresletében az egyik legfőbb tájékozódási fórum az internet, ezért a világhálón elérhetó budapesti szolgáltatásokról építettünk adatbázist. Összegyújtöttük az elérhetô szolgáltatásokat, ezeket kategorizáltuk, valamint elemeztük mennyiségi és minőségi mutatóikat. Azokra a szolgáltatásokra koncentráltunk, amelyek a turisták által nyomon követhetóen keresettek, így az adatbázis-építés során nagyban támaszkodtunk a véleményoldalakon és a gyújtőoldalakon elérhetố adatokra. A kutatás második (2015. március-augusztus), negyedik (2016. március-augusztus) és hatodik szakaszában (2017. március-augusztus) az első szakaszban felépített szolgáltatási adatbázis újrafelvételezésével annak változásait figyeltük. A longitudinális vizsgálat során elemeztük a szolgáltatások számában, öszszetételében és elhelyezkedésében megmutatkozó területi jellemzóket és változásokat, valamint nemzetközi kitekintésben értékeltük Budapest helyzetét egy kiválasztott szolgáltatáscsoport esetében. A nemzetközi konkurenciaelemzést először a környező országok fóvárosainak, majd az EU28 országok fôvárosainak a kínálatára végeztük el a Tripadvisor weboldal adatbázisa segítségével. Kutatásunk harmadik (2015. szeptember-október) és ötödik szakaszában (2016. szeptember-október) megvizsgáltuk a kiválasztott szolgáltatáscsoport kínálatának ismertségét egy adott keresleti szegmensben.

A kutatás részeként a teljes időszakban több alkalommal, terepbejárást végezve személyesen vettünk részt a programokon (color run, escape rooms, transdance). Emellett közel 180 szolgáltatás esetében honlapelemzést is végeztünk.

\section{Kutatási eredmények}

A kutatás során számos olyan korábban nem vizsgált, vagy kevésbé ismert idegenforgalmi adottságot tártunk fel, ahol a kreativitás és az aktivitás hangsúlyos eleme a szolgáltatásnak. Kutatásunk egyik legfontosabb eredménye éppen az volt, hogy a felmért kínálatot kategorizáltuk, és áttekinthetô formába rendeztük (1. ábra). 


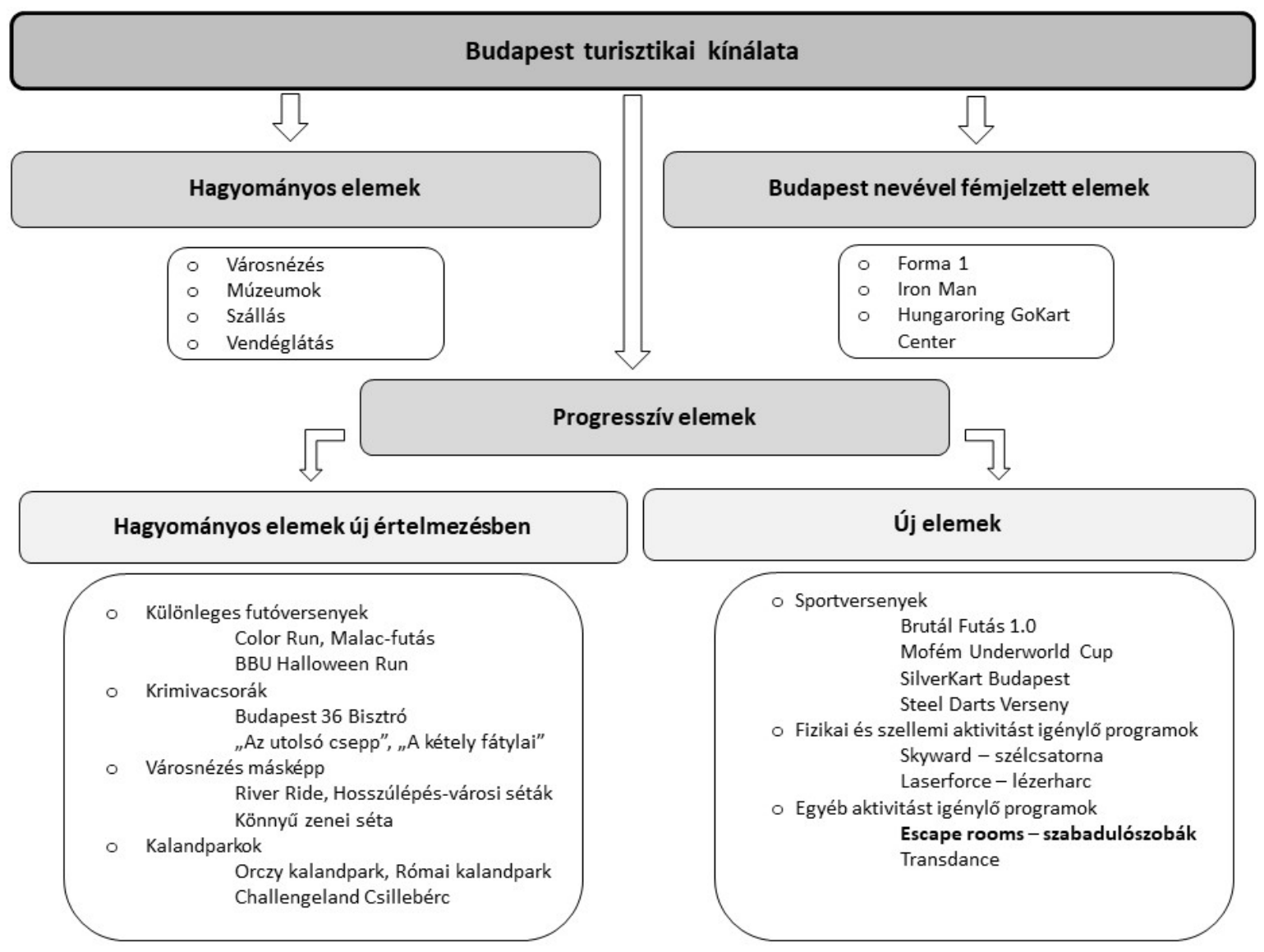

Forrás: saját szerkesztés

A kategóriák kialakításának két szempontja a szolgáltatási kínálat újdonságértéke és területi elhelyezkedése volt. A feltárt szolgáltatási elemek területi elhelyezkedése során külön vizsgáltuk, hogy azok milyen mértékben koncentrálódnak Budapestnek arra a központi területére, amely a turisták által hagyományosan bejárt területnek minősül, valamint milyen arányban jelennek meg a turista zónán kívül esố városi terekben. A kínálati elemek között az alábbi kategóriákat különböztettük meg:

- hagyományos kinálati elemek, amelyek hagyományosan ismert formában, hosszú ideje rendelkezésre álló szolgáltatások;

- Budapest nevével fémjelzett elemek, amelyek a fóvároshoz közeli helyszínen megvalósuló kreatív szolgáltatások és rendezvények;

- progresszív elemek, amelyek lehetnek hagyományos kínálati elemek új értelmezésben, vagy teljesen új, elôzményekkel nem rendelkezó kínálati elemek, szolgáltatások.
Jelen tanulmányunk témaválasztásához kapcsolódóan Budapest új vagy újszerú szolgáltatásairól szólunk részletesen.

Az innovatív és kreatív idegenforgalmi kínálatban - a hagyományos szolgáltatási elemek esetében is, mint városnézés, vendéglátás, témaparkok, múzeumok, rendezvények - egyre többször bukkannak fel szokatlan helyszínek, szokatlan közlekedési eszközök vagy új tematikák, tükrözve a szolgáltatók útkeresését és kreativitását. Budapest progresszív (új vagy újszerû) szolgáltatásainak kategóriáját ezért további két csoportra osztottuk fel: egyrészt megkülönböztettük azokat a hagyományos kínálati elemeket, amelyeket új módon kínálnak a szolgáltatók, másrészt elkülönítettük a teljesen új kínálatot jelentô szolgáltatásokat.

A hagyományos kínálat új értelmezésben való megjelenésére jó példaként említhetôk az utcai színi előadással egybekötött városnézó séták (ghost tour), a krimivacsorák, valamint a futóversenyek köréból a color run. 
Lektorált tanulmányok

A kínálat teljesen új oldalához azokat a kreatív szolgáltatásokat soroltuk, amelyek előzmény nélkül bukkantak fel a hazai piacon. Budapest ezen a téren is számos alternatívát kínál, amelyeket az aktivitás mértéke és minősége szerint rendeztünk csoportokba. Ezeket a szolgáltatásokat három csoportba sorolhatjuk: a) sportversenyek, b) fizikai aktivitást és szellemi koncentrációt igényló programok, valamint c) egyéb aktivitást igénylő programok.

A sportversenyek között említhetők a városi akadályfutások (például Burger King Brutálfutás Budapest 1.0, amelyet a 2012-es nyáregyházi rendezvény sikerén felbuzdulva Budapesten 2014-ben rendeztek meg az elsô alkalommal). Igazi újdonságnak számít az extrém akadályfutás a terep sajátossága és a városi életre jellemző épített akadályok miatt. Ebbe a csoportba sorolhatók a földalatti kerékpárversenyek is (például Mofém Underworld Kupa, amelyet 2010 óta rendeznek meg Kőbányán egy világviszonylatban is egyedülálló helyszínen, a sörgyár pincerendszerében, a 3-8 m széles, kanyargós, részben teljesen sötét földalatti folyosókon).

A fizikai aktivitást és szellemi koncentrációt igénylố programok körébe olyan egyre kedveltebb szolgáltatásokat sorolhatunk, mint a fedett szélcsatorna (skyward), amely 2013 óta üzemel a Csepel-sziget északi csúcsán, és rövid elméleti felkészítés után lehetôséget ad a szabadesés kipróbálására. A maga nemében egyedülálló szolgáltatás volt a vizsgált időszakban, hiszen Európában mindössze nyolc másik városban volt hasonló szolgáltatás. De említhetjük a lézerharcot (laserforce) is, amely 2011 óta érhetó el Budapesten. Az érdeklódők jelenleg 11 pályán vívhatnak lézercsatákat speciális felszereléssel. Hasonló szolgáltatások a fốváros más területein szabadban és használaton kívüli gyárcsarnokokban is elérhetóek.

Az egyéb aktivitást igénylő szolgáltatások körét gazdagítják a szabadulószobák (escape rooms), amelyek 2011-ben jelentek meg Budapesten, és számuk 2013 óta jelentősen nőtt. Többségében zárt helyiségből vagy helyiségekből, változatos történetekbe ágyazott logikai és/vagy ügyességi feladatok megoldásával lehet elérni a játék célját. A transztánc (transdance) néhány éve elérhetô kínálati elem, amely jól mutatja a szolgáltatók alkalmazkodását a spirituális témák iránti megnövekedett érdeklődéshez. A tevékenység célja, hogy a résztvevő́k a látás kiiktatásával, elsósorban a hallásra és a mozgásra koncentrálva különleges tudatállapotba jussanak, és ezzel a lélek állapotát javítsák.

A fenti példák igazolják azt az előzetes feltevésünket, hogy Budapest kínálata folyamatos változáson megy keresztül, és közben meg is újul. Az is egyértelmú, hogy ezek a kínálati elemek a részt- vevő́k aktivitását igénylik, valamint innovatív és kreatív szolgáltatói magatartást mutatnak. A fenti szolgáltatások közül a szabadulószobák kínálatát mutatjuk be részletesen.

\subsection{A SZABADULÓSZOBÁK KÍNÁLATA BUDAPESTEN}

Több olyan internetes gyúitôoldal múködik (például SWEET ESCAPE ${ }^{5}$, EXIT GAMES ${ }^{6}$ ), ahol különbözô szempontok alapján rendezve érhetôk el a szabadulószobák ajánlatai. Ezen oldalak adták vizsgálatunk kiindulási adathalmazát. 2014 második felében 57, 2016-ban már 68 különböző budapesti helyszínt kínáltak ezek a weboldalak. Az elérhető szabadulójátékokat tematika, időtartam, résztvevő́k létszáma és árfekvés szerint rendszereztük. Vizsgáltuk továbbá az egyes házak területi elhelyezkedését a fóvároson belül, valamint elegendố információ esetén értékeltük a szolgáltatások minőségét. A felmért játékokat 7 témakörbe tudtuk besorolni (1. táblázat).

\section{1. táblázat}

Budapesti szabadulószobák tematikái

\begin{tabular}{|c|c|c|c|c|}
\hline & Témakör & Játék témája & 2014 & 2016 \\
\hline 1. & Kijutás & $\begin{array}{c}\text { Kijutás börtönböl, } \\
\text { pincéból, hajókabinból, } \\
\text { egyiptomi sírkamrából } \\
\text { stb. }\end{array}$ & 28 & 72 \\
\hline 2. & Nyomozás & $\begin{array}{l}\text { Nyomozás gyilkos, } \\
\text { rabló, tolvaj, ékszer, } \\
\text { eltûnt személy, térkép, } \\
\text { irat, valamilyen titok } \\
\text { stb. után }\end{array}$ & 19 & 43 \\
\hline 3. & Film & $\begin{array}{c}\text { Mese, James Bond, } \\
\text { kultfilmek }\end{array}$ & 12 & 15 \\
\hline 4. & Utazás & $\begin{array}{l}\text { Körút, dzsungel, } \\
\text { világür, múlt, jövoó }\end{array}$ & 13 & 9 \\
\hline 5. & Erotika és horror & Korhatáros játék & 6 & 4 \\
\hline 6. & \begin{tabular}{|c|}
$\begin{array}{c}\text { Ismeretterjesztés, } \\
\text { oktatás }\end{array}$ \\
\end{tabular} & $\begin{array}{l}\text { Kémia, földrajz, } \\
\text { Magyarország stb. }\end{array}$ & 3 & 1 \\
\hline 7. & Egyéb & Egyéb változatos témák & 18 & 10 \\
\hline \multicolumn{3}{|c|}{ Összesen: } & 99 & 154 \\
\hline
\end{tabular}

Forrás: SWEET ESCAPE $(2014,2016)$ és EXIT GAMES $(2014,2016)$ adatai alapján saját összesítés

A játékok számában a vizsgált idôszakban a kínálatbővülés $(+50 \%)$ egyértelmú, ugyanakkor ez nem járt együtt a szolgáltatók számának jelentős növekedésével (+20\%). A csekély számú új piaci belépó

\footnotetext{
5 https://www.szabaduloszoba.hu, Letöltve: 2014. szeptember-december és 2016. március-augusztus.

6 http://exitgames.hu/jatekhelyszinek, Letöltve: 2014. szeptemberdecember és 2016. március-augusztus.
} 
mellett tehát jellemzően a már múködő egységek bóvítették kínálatukat.

Mint azt a játék elnevezése is mutatja, a legtöbb esetben a cél maga a kijutás nem hétköznapi körülmények közül vagy helyszínekről. Gyakran választott téma a nyomozás, egy búneset felderítése. A megoldandó feladatokat, rejtélyeket sok esetben egy ismert filmhez kapcsolódóan, vagy egy utazási motívum köré építik fel. A filmes kerettörténetek esetében csekély bővülés figyelhető meg a felhasznált témakörökben: Ms. Marple alakja, a Gömb címú film, a Lost, a Harry Potter, a Másnaposok, a Trónok Harca mozifilmek, illetve a Helyszínelők (CSI) sorozat elemei bukkannak fel új témaként a korábbi kínálathoz képest.

A szabadulószobák (real-life escape rooms) megjelenése után nem sokkal feltúntek a piacon az úgynevezett második generációs szabaduló játékok is (lásd alternate reality games). A játék nem korlátozódik egy zárt térre, azaz a szobára, hanem az utcán, a környező városrészben is zajlik. Ezek tematikája általában valamilyen nyomozási feladatot tartalmaz szerepjátékkal bóvítve. Az újdonságok körét gazdagítja a „logikai kalandjáték elvitelre". A helyszínen ismertetik a kerettörténetet, és a feladat magoldásához a csapat kap egy „csomagot". Ezt akár haza is vihetik, így maga az élményszerzés nem helyhez kötött. Egyedi lehetőség és új színfoltja a szolgáltatásoknak a 2015-ös szezonban megjelent „,mobil exit room" (átalakított busz, kisebb teherautó), amit elsősorban rendezvények alkalmával a helyszínen lehet kipróbálni. A mobilitáshoz kapcsolódva felismerték a játékban rejlő promóciós lehetőségeket is, több elektronikai, músorszóró és olajipari multinacionális vállalat alkalmazott már termék- vagy toborzási kampányai során „mobil szabadulószobát”. Az elmúlt években újabb szegmensként egyre több céges rendezvény és csapatépítő tréning helyszínéül választják a szabadulószobákat.

A feladatok megoldására a játékosoknak a legtöbb esetben 60 perc áll rendelkezésükre, de vannak eltérő hosszúságú játékok is. 2016-ban megjelent egyedi megoldás, amikor egy játékban 30 percról indul a csapat, és sikeres feladatmegoldással először időt lehet nyerni (legfeljebb megduplázni a rendelkezésre álló időt) a küldetés eredményes teljesítéshez. Új innovatív elem a „villám szabadulószoba” megjelenése, amelyek általában az állandó rendezvényhelyszíneken várják az érdeklődőket. A feladat elvégzéséhez rendelkezésre álló idő ebben az esetben 15-30 perc között mozog. Ily módon a koncertek, rendezvények előtt vagy után is próbára tehetô a kreativitás. Egyes helyszínek lehetôvé teszik két játék egymásba kapcsolását is, vagyis a játéko- sok az egyik játéktérből közvetlenül egy másikba jutnak át. Ebben az esetben a játék idótartama is megduplázódik.

A résztvevők száma általában 2-6 fő, igazodik a játékok színteréül szolgáló szobák, illetve helyiségek méreteihez. Nagyobb létszámú csoportok fogadására akkor van mód, ha a szabadulószoba lehetôséget biztosít rá, hogy egy időben egyszerre több szobában is játszhassanak a vendégek. Ebben az esetben 24-30 résztvevő fogadása is lehetséges, akik azonban csoportonként más-más helyiségekben játszanak. Az újdonságok közé tartozik, hogy egy helyszínen lehetőség van két csapat versenyére is, ahol azonos feladat gyorsabb megoldásában versenyezhetnek a csapatok. Szintén az egy időben történó játékokhoz kapcsoló új elem, amikor a csapatok szabályozott keretek között egymást akadályozhatják a feladat megoldásában. Mint láthatjuk, az élményszerzés újabb és újabb variációi épülnek be a szabadulószobák kínálatába.

A vizsgált szolgáltatások ára elég egységes képet mutat. A legtöbb esetben csoportonként 10.000, illetve $12.000 \mathrm{Ft}$ a meghirdetett ár a 2-6 fős csoportok számára. Ebből az árból több játékhelyszín különböző nagyságú kedvezményt ad. Kuponnal, diákigazolvánnyal, vagy rejtvény megoldásával a belépődíj esetenként 20-50\%-kal is csökkenhet. Az is jellemző, hogy a játék végeztével a résztvevők kedvezményes kupont kapnak a következő játék kipróbálására. Új elem a fizetésben, hogy 2016-tól 7 helyszínen a költségeket SZÉP-kártyával is lehet rendezni.

A szabadulószobák esetében természetesen nem számolhatunk azzal, hogy a játékok résztvevői valamennyien turisták lennének. A kereslet elemzését lehetôvé tévő adatbázisok nem állnak rendelkezésre, illetve a szolgáltatók nem gyújtenek ilyen jellegú adatokat. Így a kereslet összetételének megismerésére csak egy átfogó primer kutatás adhatna lehetôséget. A kínálat folyamatos bôvítése, valamint a szolgáltatások jellemzői viszont egyértelmúen alátámasztják azon feltételezésünket, miszerint a turisták növekvő számban vannak jelen a szabadulószobák résztvevői között. A szolgáltatás idegenforgalmi térnyerését támasztja alá, hogy a városlátogató vendégforgalom növekedésével párhuzamosan egyre több turisztikai helyszín és szolgáltatás kínálatában találkozunk a szabadulószobákkal. Nem véletlen, hogy 2011 után a szolgáltatás a külföldiek által is kedvelt romkocsmák pincéiból nőtte ki magát sikertörténetté (BIRKÁS 2016). A nemzetközi TripAdvisor véleményoldalon 2013ban született meg az elsó értékelés a játékokról, ami gyorsan növelte a szolgáltatások ismertségét, és hozzájárult népszerúségük robbanásszerú növekedéséhez (LAZA 2018). 
Lektorált tanulmányok

A szolgáltatás nagy elónye a viszonylag egyszerú kivitelezhetősége és rugalmassága, így a hagyományos turisztikai szolgáltatók palettáját is színesíti. Napjainkban már szálláshelyek, múzeumok és vendéglátó egységek is kínáliák ezt a szolgáltatást. Találkozhatunk vele a Gellért Szállodában főszezonon kívül, a Király Fürdőben, a Magyar Természettudományi Múzeumban, a Magyar Nemzeti Múzeumban, a Gozsdu Udvarban, továbbá a Gondozó és a Füge Udvar nevú romkocsmákban (ORIGO 2017). A szabadulós játékok promóciós értékét és sikerét felismerve a Magyar Turisztikai Ügynökség a Sziget fesztiválon 2016-ban elindította a mobil szabadulás lehetőségét, amelyet hazánkról szóló ismeret-átadással kapcsolt össze.

A turizmus szempontjából lényeges jellemzője a szolgáltatásnak, hogy a vizsgált időszakban az angol nyelven játszható játékok aránya jelentősen (31\%-ról 42\%-ra) nótt, vagyis a szolgáltatás egyértelmúen nemzetközivé vált. Még ennél is magasabb (52\%) azoknak a szolgáltatóknak az aránya, akik idegen nyelvú (elsősorban angol) honlapon kínálják a szabadulójátékokat.

Bár még egészen új szolgáltatással állunk szemben a kínálati piacon, máris elindult az értékeló, minősító folyamat. Ezt a szolgáltató érdekei mellett a széles kínálat és a fokozódó érdeklódés is indokolja. 2014-ben a vizsgált szolgáltatói körben még csak 13 helyszínen értékelhették a vendégek a játékokat egy ötfokozatú Likert-skálán a témakör/ kreativitás/nehézség szempontjából. 2016 tavaszára jelentős előrelépés történt a minősítések terén: a játékok közel fele kéri a látogatók véleményét, illetve a játékosok a közösségi oldalakon és blogokban is elmondhatják tapasztalataikat és véleményüket az egyes helyszínekről. A minósítés módszere viszont továbbra sem egységes. A minősítési és véleményezési folyamat egységesebb keretek között követhetố nyomon a TripAdvisor oldalain, ahol 2016-ban a szórakozás és játékok kategóriában 49 szabadulószobáról találtunk számszerúsíthetô és szöveges értékelést. A résztvevők szavazatai alapján 2014-ben és 2015-ben egyaránt kiadták az „Ev legjobb szabadulójátéka" címet, valamint a Magyar Beutaztatók Szövetsége 2015-ben „Az év turisztikai termékének" választotta a szabadulószobákat (DEVECSAI 2015). 2015-tól minden évben október közepén rendezik meg a „Szabadulószobák éjszakája" programot, amellyel hagyományt kívántak teremteni. A figyelem felkeltése és a folyamatos megújulás tehát már ennél a szolgáltatásnál is követelménnyé vált. A szabadulószobák töretlen népszerúségét mutatja, hogy 2017 márciusában lezajlott az első szabadulószoba világbajnokság, amely online játékként indult, azonban a budapesti döntőre több mint 40 országból érkeztek verseny- zők․ Az elmúlt években a szolgáltatás a vidéki települések kínálatában is megjelent, kutatásaink szerint napjainkban mintegy száz játék található vidéki helyszíneken. Elsősorban a megyeszékhelyeken és a jelentősebb turisztikai vonzerővel és vendégforgalommal rendelkező településeken találkozhatunk szabadulószobákkal. A települések között Budapest után Debrecen mutatja a legnagyobb aktivitást a szabadulószobák terén (8 játék), míg a legnagyobb vidéki kínálattal a Balaton-part rendelkezik (5 településen 11 szabadulószoba). A vidéki helyszínek között két unikális elem is van, mindkettő eredeti helyszínen játszható: a „Szabadulótanya" Sarlóspusztán és a „Szabotázs a bányaüzemben" egy valamikori bánya területén Oroszlányban.

\subsection{NEMZETKÖZI KITEKINTÉS}

A városi turizmus növekvő keresletéért folyamatos verseny zajlik a nagyvárosok között. Budapest versenyképességének szempontjából fontos kérdés, hogy a szabadulószobák gazdag és sokszínú tárháza vajon milyen kínálatot jelent nemzetközi összehasonlításban?

FRENCH és SHAW (2015), valamint STASIAK (2016) kutatásai alapján megállapíthatjuk, hogy nemzetközi összehasonlításban Budapest kiemelkedô pozícióval rendelkezik a szabadulószobák terén. A szabadulószobák ranglistáját 2015-ben az Escape Room Directory adatbázisa szerint Peking vezette 182 szobával. A kínai hegemóniát jól mutatja, hogy a kínai fóvárost 7 további kínai nagyváros követi 66-110 közötti szobaszámmal, majd egyetlen nem ázsiai toplistás városként Budapest következik 63 szabadulószobával. Budapesten kívül csak Moszkva (46), London (36) és Bukarest (34) kerültek fel európai nagyvárosként a toplistára. Budapest jelentőségét mutatja az is, hogy az európai kínálati palettán több fóváros esetében (például London, Bécs, Pozsony, Bukarest, Brüszszel) a szolgáltatás magyar közvetítéssel jelent meg és fejlődött tovább a helyi igényeknek megfelelően (HERMANN 2015).

Saját kutatásunkban a nemzetközi összehasonlítás alapjának a TripAdvisor véleményoldal adatait vettük. A vizsgált kínálati elem a Szórakozás és játékok kategórián belül 2015 óta nevesítetten megtalálható. Csak azoknak a szolgáltatásoknak az adatait vizsgáltuk, amelyek a TripAdvisor oldalain a mintavétel idópontjában megjelentek. A weboldal lehetôvé teszi a városokra történő rákeresést, a keresési eredményekben pedig külön jeleníti meg, és a vélemények alapján rangsorolja

7 https://www.exittheroom.hu/blog/szabaduloszoba-vilagbajnoksagbudapesten 


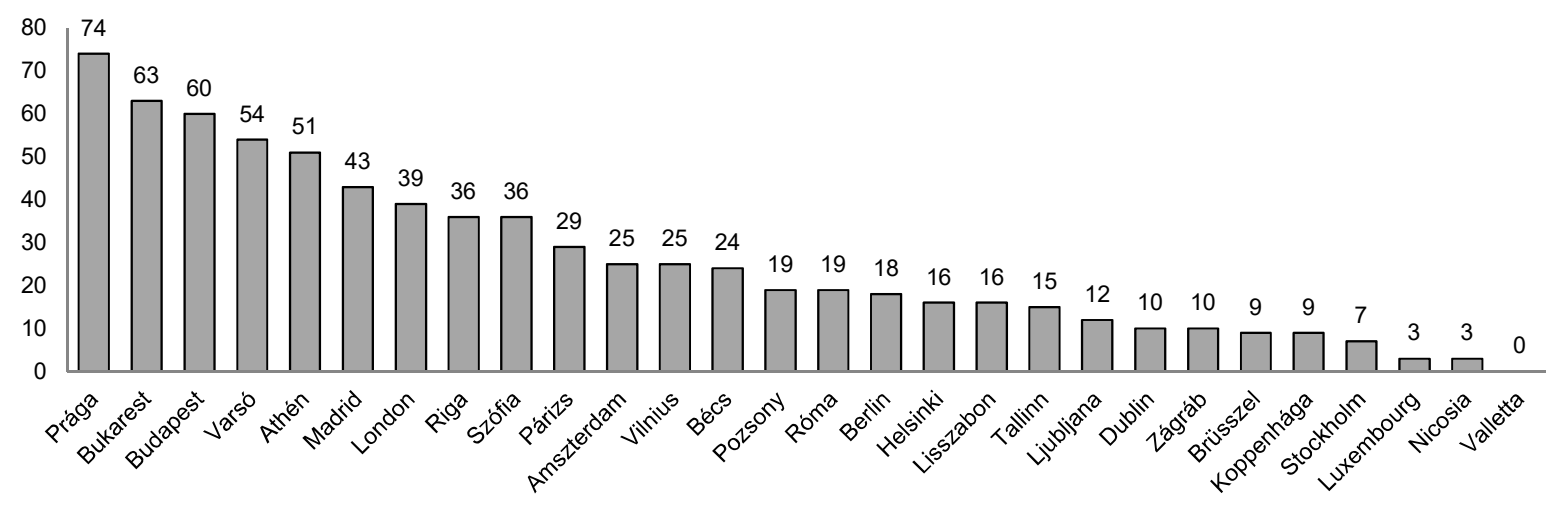

Forrás: saját összesítés a TRIPADVISOR (2017) adatai alapján

A szabadulószobák kínálatának alakulása a kelet-közép-európai fôvárosokban (2015-2017)

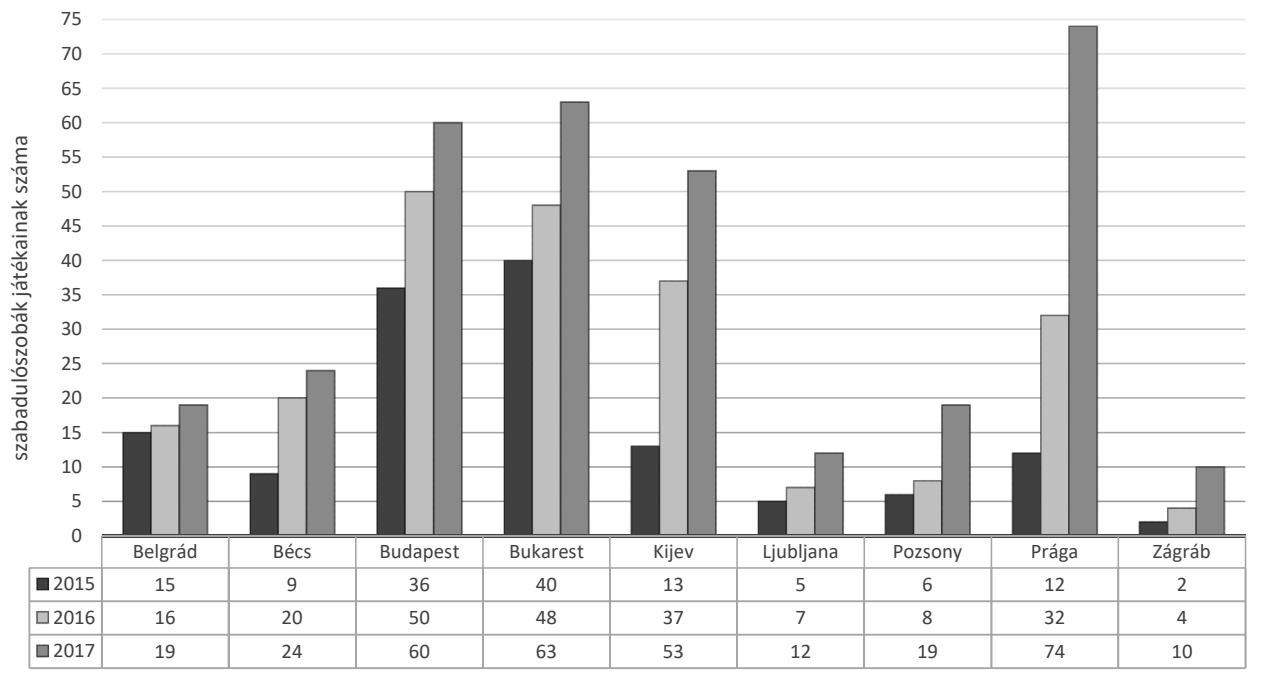

Forrás: saját összesítés a TRIPADVISOR (2017) adatai alapján

a szabadulószobákat. A budapesti eredmények rámutattak arra, hogy ezen a felületen nem szerepel valamennyi múködő szolgáltatás. További módszertani problémaként jelentkezett, hogy az egyes szolgáltatók eléréséhez megadott weboldalak több átfedést is tartalmaznak, illetve elófordultak olyanok is, ahol a megadott címen már nem volt elérhető a szolgáltatás.

2017 nyarán a TripAdvisor szerint az Európai Uniós fóvárosokban összesen 725 escape room szolgáltatóról adtak véleményt a résztvevők (2. ábra).

A játékok száma alapján, európai szinten Budapest legnagyobb versenytársai Prága, Bukarest, Varsó és Athén. Ha a játékok számának alakulását a hazánkkal szomszédos fóvárosok és Prága, mint legközelebbi versenytárs szempontjából vizsgáljuk, árnyaltabb képet kapunk. Az összehasonlítást a játékok számáról, tematikai jellemzőirôl, valamint a vélemények alakulásáról a 2015 és 2017 közötti időszakra végeztük el (3. ábra).

A budapesti kínálatra vonatkozó vizsgálataink már rámutattak a szabadulószobák népszerúségére és a szolgáltatások számának növekedésére. Hasonló tendenciát mutat a szomszédos fővárosok kínálatának fejlődése is: a vizsgált helyszíneken a kínálat évról-évre eltérő ütemú, de folyamatos bővülést mutat. A kilenc vizsgált fóvárosban a szabaduló szolgáltatásokat nyújtó helyszínek száma 138-ról 334-re emelkedett. A szolgáltatók többsége általában kétféle játékot ajánl a látogatóknak, így 
Lektorált tanulmányok

a 334 helyszínen közel 700 játék próbálható ki. A fóvárosok közül kiemelhető Prága, Kijev és Bécs, ahol a szolgáltatások száma megháromszorozódott a vizsgált idószakban. A teljes kínálatot tekintve Budapest $(17,9 \%)$ mellett Prága (22,15\%), Bukarest $(18,8 \%)$ és Kijev (15,8\%) részesedése emelhető ki.

A szolgáltatástípusok nemzetközi összehasonlításában a budapesti játékoknál kialakított besorolást alkalmaztuk (lásd 1. táblázat). Nemzetközi téren a két legnépszerúbb játéktípus a kijutás $(47,5 \%)$ és a nyomozás (32\%), amelyek mind a kilenc fóvárosban megtalálhatók. A fóvárosok kínálatában többnyire megtalálható a bunker, a börtön, az egyiptomi piramis és a labirintus. Állandó téma a II. világháború, a volt szocialista országokban pedig a kommunista rendszer vagy a titkos ügynökök. A tematikákkal kapcsolatban érdemes kiemelni, hogy az ismeretterjesztés jelentósége - hasonlóan Budapesthez mindenhol visszaszorulóban van: a kilencből hét fơvárosban jelenik meg és számuk egyre csökken. $\mathrm{Az}$ ismeretterjesztő tematikával múködő játékok egy része második generációs játék, tehát nem zárt helyiségekben, hanem városi színtéren zajlanak. Ebben az esetben a város nevezetességeinek vagy a város nevezetes személyiségeinek (például Nicola Tesla) és a hozzájuk köthető örökségnek, tudományos felfedezéseknek van szerepe, vagy valamely tudományterület (fizika, kémia, matematika, földrajz) ismereteinek a hasznosítása a cél. Kiemelhetjük még a filmekhez, sorozatokhoz köthetó tematikákat (például a Gyúrúk ura, a Harry Potter, az Indiana Jones, a Trónok harca, vagy a James Bond filmekre alapozott játékok), amelyek több fóvárosban is megjelennek. Egyedi ötlet, hogy Bécsben és Bukarestben csapatok is versenyezhetnek egymással, vagy hogy egyetemi vizsgaszituációt keltenek életre a játék keretében, esetleg a legmodernebb IT-technológiát vetik be a közönség megnyerésére (például nyomozás tablettel speciális applikáción keresztül, virtuális szemüveg alkalmazása).

\section{5. Összefoglalás}

A nemzetközi és hazai szakirodalom áttekintése rámutatott arra, hogy az alternatív turizmus és azon belül a kreatív turizmus jelentősége és kínálata nemzetközi szinten egyértelmúen nőtt az elmúlt évtizedben. A vendégforgalmi adatok elemzése rámutatott arra, hogy Budapest szerepe a nemzetközi turizmus piacán lassan, de biztosan nő. Budapest pozícióját jelentősen javíthatják, és egyfajta kitörési pontként jelenhetnek meg azon szolgáltatások, amelyek a helyi vállalkozók innovativitásán és kreativitásán alapulnak.

Kutatásunk egyik meghatározó eredménye a teljes budapesti szabadidős programkínálat kre- atív és aktív elemeinek összegyújitése, rendszerezése és kategorizálása. A kategóriák kialakításában kulcsfontosságú szerepe volt a szolgáltatások újdonságértékének, innovativitásának és területi elhelyezkedésének. Ennek alapján a budapesti turisztikai szolgáltatásokat hagyományos kinálati elemekre, Budapest nevével fémjelzett elemekre, valamint progresszív elemekre osztottuk fel. Utóbbi csoportban különválasztottuk azokat a hagyományos kínálati elemeket, amelyeket új módon kínálnak a szolgáltatók azoktól, amelyek teljesen új kínálati elemet jelenítenek meg.

A szolgáltatások közül kiválasztottuk és részletesen bemutattuk azt a szolgáltatástípust, amely a vizsgálataink alapján rendkívül dinamikusan fejlődött az elmúlt évtizedben: a szabadulószobákat. A szabadulószobák óriási fejlődésen mentek keresztül az elmúlt években, számuk ugrásszerúen nőtt, a tematikák köre gyorsan bôvült. A részletes elemzések rámutattak arra, hogy Budapestnek valóban létezik olyan innovatív kínálata, amely egyrészt folyamatosan fejlódik, másrészt hozzájárul a fóváros turisztikai kínálatának megújulásához. Fontos kiemelni azt a tényt is, hogy ez a szolgáltatási kínálat az alternatív turizmus kínálatához tartozik, tehát a fóvárosnak azokat a lehetôségeit bóvíti, amelyek - illeszkedve a nemzetközi trendekhez - az egyéni igényeket elégítik ki. A kínálat elemzése, valamint a szolgáltatások egyes jellemzői megerősítették azt a feltételezésünket, miszerint a turisták egyre növekvő számban vannak jelen a szabadulószobák játékaiban résztvevők között.

A szabadulószobák fejlődésére jellemző, hogy a klasszikus, zárt terekben zajló játékok mellett megjelentek a második generációs játékok, amelyek a zárt térből kilépnek a városi helyszínekre, nyitott terekre. A szolgáltatás „virulenciáját" jelzi az alkalmazott tematikák sokszínúsége, a játékok változatossága és a helyszínek széles kínálata, a szolgáltatás rugalmassága és mobilizálhatósága.

A szabadulószobák hazai elterjedésében egyértelmúen visszaköszön a piac nagysága, vagyis a turisztikai desztinációk vendégforgalom alapján elfoglalt pozíciója, illetve az érintett települések nagysága. A legtöbb szolgáltatással Budapesten és a Balaton partján találkozunk, emellett kiemelhetốk a nagyvárosok (regionális centrumok és megyeszékhelyek).

Nemzetközi összehasonlításban Budapest pozíciója kiemelkedő. Maga a szolgáltatás több európai nagyvárosba magyar közvetítéssel jutott el, így Budapest sok tekintetben lépéselónnyel rendelkezik a versenytársaival szemben. A kínálati piac azonban rendkívül dinamikusan bővül minden környező nagyvárosban, ezért Budapest versenyelónyének 
megơrzésében és a szegmens fejlődésében továbbra is meghatározó szerepet fognak játszani az új, kreatív és innovatív megoldások.

Jövőbeli primer kutatásunk a kereslet igényeinek, számosságának és legfontosabb jellemzóinek a vizsgálatára összpontosít. Ennek során választ szeretnénk majd kapni arra a kérdésre is, hogy a kreatív és aktív szolgáltatási kínálat bôvülése vajon kimutatható-e a vendégforgalom bővülésében?

\section{Köszönetnyilvánítás}

A tanulmány elkészítését részben a Nemzeti Kutatási, Fejlesztési és Innovációs Hivatal 128717. számú „Progresszív városföldrajz - A városverseny meghatározó tényezői Magyarországon" projektje támogatta.

\section{Felhasznált irodalom}

BOES, K. - BUHALIS, D. - INVERSINI, A. (2015): Conceptualising smart tourism destination dimensions. In: Tussyadiah, L. - Inversini, A. (eds): Information and communication technologies in tourism. Springer, Wien. pp. 391-403.

BULENCER, P. - EGGER, R. (2015): Gamification in Tourism, designing memorable experiences. Books on Demand, Norderstedt.

CORREA, C. - KITANO, C. (2015): Gamification in Tourism: Analysis of Brazil Quest Game. e-Review of Tourism Research. 6. pp. 1-5.

DETERDING, S. - DIXON, D. - KHALED, R. - NACKE, L. E. (2011): From game design elements to gamefulness: Defining "Gamification". Mindtrek 2011 proceedings. ACM Press, Tampere, Finland.

DEVECSAI J. (2015): Fejtörók közé zárnak. Figyeló. 54(27). p. 59.

GRETZEL, U. - JAMAL, T. (2009): Conceptualizing the creative tourist class: Technology, mobility, and tourism experiences. Tourism Analysis. 14(4). pp. 471-481.

HERMANN I. (2015): Bezárunk titeket egy szobába, és jó lesz. Forbes. 3(2). pp. 44-47.

LAZA B. (2018): Kiszabadultunk a világba. Forbes. 10. pp. 33-44.

MICHALKÓ G. (2012): Turizmológia. Akadémiai Kiadó, Budapest.

NEGRUŞA, A. L. - TOADER, V. - SOFICA, A. TUTUNEA, M. F. - RUS, R. V. (2015): Exploring Gamification Techniques and Applications for Sustainable Tourism. Sustainability. 7(8). pp. 11160-11189.

NEUHOFER, B. - BUHALIS, D. - LADKIN, A. (2012): Conceptualising technology enhanced destination experiences. Journal of Destination Marketing $\&$ Management. 1(1-2). pp. 36-46.

PAN, R. - LO, H. - NEUSTAEDTER, C. (2017): Collaboration, awareness, and communication in real-life escape rooms. DIS Conference paper, Edinburgh, UK. pp. 1353-1364.

RÁTZ T. (2015): Alternatív városnézés Budapesten: globális innováció vagy lokális szolgáltatásfejlesztés? In: Rátz T. - Michalkó G. (szerk.): Kreativitás és innováció a turizmusban. Turizmus Akadémia 7. Kodolányi János Fơiskola, Budapest. pp. 79-90.

RICHARDS, G. - RAYMOND, C. (2000): Creative tourism. ATLAS News. 23. pp. 16-20.

RICHARDS, G. - WILSON, J. (2007): Tourism, creativity and development. Routledge, London.

RICHARDS, G. (2009): Creative tourism and local development. In: Wurzburger, R. - Pattakos, A. - Pratt, S. (eds): Creative Tourism: A global conversation. Sunstone Press, Santa Fe. pp. 7890.

RICHARDS, G. (2011): Creativity and tourism: The state of the art. Annals of Tourism Research. 38(4). pp. 1225-1253.

SEABORN, K. - FELS, D. I. (2015): Gamification in thoery and action: A survey. International Journal of Human-Computer Studies. 74. pp. 14-31.

SHARPLEY, R. (2015): Postmodernism, tourism. In: Jafari, J. - Xiao, H. (eds): Encyclopedia of tourism. Springer, Cham. pp. 1-3.

SIGALA, M. (2015): Gamification for crowdsourcing marketing practices: Applications and benefits in tourism. In: Garrigos-Simon, F. J. Gil-Pechuán, I. - Estelles-Miguel, S. (eds): Advances in crowdsouring. Springer, Cham. pp. 129-145.

SMITH, W. L. (2006): Experiential tourism around the world and at home: definitions and standards. International Journal of Services and Standards. 2(1). pp. 1-14.

SMITH, M. K. - EGEDY, T. - CSIZMADY, A. JANCSIK, A. - OLT, G. - MICHALKÓ, G. (2018): Non-planning and tourism consumption in Budapest's inner city. Tourism Geographies. 20(3). pp. 524-548.

STASIAK, A. (2016): Escape rooms: A new offer in the recreation sector in Poland. Tourism. 26(1). pp. 31-47.

XU, F. - BUHALIS, D. - WEBER, J. (2017): Serious games and the gamification of tourism. Tourism Management. 60. pp. 244-256.

XU, F. - WEBER, J. - BUHALIS, D. (2014): The gamification of tourism. In: Xiang, Z. - Tussyadiah, I. (eds): Information and communication technologies in tourism. Springer, Wien. pp. 525-537. 
Lektorált tanulmányok

ZÁTORI A. (2014): Alternatív városnéző túrák Budapesten. In: Jászberényi M. (szerk.): $A$ kulturális turizmus sokszinúsége. Nemzeti Közszolgálati és Tankönyv Kiadó, Budapest. pp. 275-288.

\section{Internetes források}

BIRKÁS P. (2016): Szabadulószoba világbajnokság érkezik Budapestre. http://www.origo.hu/ techbazis/20161130-red-bull-mind-gamesmission-unlock-enoch-escape-roomszabaduloszoba-bajnoksag-2017.html, Letöltve: 2017. február 20.

CCN (Creative Cities Network) (2008): Towards Sustainable Strategies for Creative Tourism. Descussion Report of the Planning Meeting for 2008 International Conference on Creative Tourism. Santa Fe, New Mexico, USA, October 25-27, 2006. http://unesdoc.unesco.org/ images/0015/001598/159811e.pdf, Letöltve: 2014. november 27.

EU (2016): Urban Europe. Statistics on Cities, Towns and Suburbs 2016 edition. http://ec.europa.eu/ eurostat/en/web/products-statistical-books/-/ KS-01-16-691, Letöltve: 2017. november 28.

EXIT GAMES (2014，2016): http://exitgames.hu/ jatekhelyszinek

FRENCH, S. - SHAW, J. M. (2015): The unbelievably lucrative business of escape rooms. http://www. marketwatch.com/story/the-weird-newworld-of-escape-room-businesses-2015-07-20, Letöltve: 2017. augusztus 15.
KEA (KEA European Affairs) (2006): The Economy of Culture in Europe. Brussels: KEA. http:// www.keanet.eu/ecoculture/studynew.pdf, Letöltve: 2018. szeptember 4.

NICHOLSON, S. (2015): Peeking Behind the Locked Door: A Survey of Escape Room Facilities. White Paper. http://scottnicholson. com/pubs/erfacwhite.pdf, Letöltve: 2018. szeptember 15.

NICHOLSON, S. (2016): The state of escape: Escape room design and facilities. http://scottnicholson. com/pubs/stateofescape.pdf, Letöltve: 2018. szeptember 15.

ORIGO (2017): Azért fizetnek, hogy bezárják óket. http://www.origo.hu/gazdasag/20171004-megmindig-jovedelmezoek-a-szabaduloszobak. html, Letöltve: 2017. szeptember 10.

SWEET ESCAPE (2014, 2016): https://www. szabaduloszoba.hu

TRIPADVISOR (2017): https://www.tripadvisor. co.hu/Attractions-g274887-Activities-c56-t208Budapest_Central_Hungary.html, Letöltve: 2017. augusztus 31.

UNITED NATIONS (2014): World urbanization prospect. Department of Economic and Social Affairs, New York. https://www. compassion.com/multimedia/worldurbanization-prospects.pdf, Letöltve: 2018. szeptember 4 .

WTM (World Travel Market) (2011): World travel market global trends report. http://www. toposophy.com/files/1/files/onsite_global_ trends_v3_lo.pdf, Letöltve: 2018. október 10. 